\title{
Biocomposites reinforced with natural fibers:thermal, morphological and mechanical characterization
}

\author{
Alessandra Luiza de Lemos ${ }^{1}$, Pamela Galera Prestes Pires ${ }^{1,2}$, \\ Marcelo Lopes de Albuquerque ${ }^{1}$, Vagner Roberto Botaro ${ }^{2}$, \\ Jane Maria Faulstich de Paiva ${ }^{2}$, Nei Sebastião Domingues Junior ${ }^{1}$
}

\author{
${ }^{1}$ ArtecolaQuímica SA, Campo Bom, RS, Brasil \\ e-mail: alessandra.lemos@artecola.com.br; pamela.prestes@artecola.com.br; marcelo.albuquerque@artecola.com.br; \\ nei.domingues@artecola.com.br \\ ${ }^{2}$ Programa de Pós-graduação em Ciência dos Materiais - UFSCar - Campus Sorocaba/SP \\ e-mail: vagner@ufscar.br; jane@ufscar.br
}

\begin{abstract}
This study evaluates the thermal, morphological and mechanical behavior of polypropylene (PP) composite with different natural fibers. The fibers used were wood, sugarcane, bamboo, babassu, coconut and kenaf with and without coupling agent. The thermal, morphological and mechanical properties were evaluated, and a composite PP+GFPP (glass fiber) was used as reference. The interaction at the interface fiber-polymer matrix was studied by scanning electron microscopy (SEM) at the fractured surface of the composites, as expected the presence of maleic anhydride (MA) as coupling agent increasedthe interaction at the interface. The influence of natural fiber in the degree of crystallinity of the composites was evaluated by DSC analysis. The samples of $\mathrm{PP}+\mathrm{GFPP}$ and $\mathrm{PP}+(\mathrm{PP}-\mathrm{MA})+\mathrm{WF}$ (wood flour) showed better temperature stability. $\mathrm{PP}+\mathrm{GF}$ also presented superior flexural modulus. The thermal dynamic mechanical behavior was evaluated by DMA, a decrease in storage modulus with increasing temperature was observed, the $\mathrm{PP}+\mathrm{GF}$ and the composite containing maleic anhydride and sugarcane fiber showed higher modulus. The natural fiber biocomposites studied, consistently presented lower flexural modulus and tensile strength than the reference composite, with and without the use of coupling agent. As expected the use of natural fibers lowered the density compared to the reference material.
\end{abstract}

Keywords: fibers; biocomposites; properties; polypropylene; DMA.

\section{INTRODUCTION}

The growing interest in products with lower environmental impact makes the use of natural fibers as reinforcing agents a viable technical alternative. The use of bio-sourced materials is increasing in an attempt to reduce the amount of thermoplastic polymers from non-renewable sources. Some environmental advantages over glass fiber are biodegradability, recyclability, reduced environmental impact, $\mathrm{CO}_{2}$ capture, lower density and lower abrasiveness. Due to this, different natural fibers have been used in composites with polymers, such as wood flour, coconut fiber, cotton, jute, sisal, curauá, kenaf and bamboo. The biggest challenges that involve composite materials are good interface interaction between the natural fiber and the polymer matrix.

A poor interaction when load is applied could compromise the resistance of the material. Coupling agents as maleic anhydride, for example, can improve the matrix/fiber interaction, by modifying the fiber surface or the matrix [ $\underline{1}-\underline{8}]$. When properly compounded natural fibers make good candidates to replace currently used glass fiber as reinforcing agent, in addition to that, they are abundant and renewable and can be generally considered as biodegradable and non-toxic. In products for the automotive market, they are often used combined with a polypropylene matrix, which has low cost and processing temperature, in order to guarantee the thermal stability $[\underline{5}, \underline{8}-\underline{10}]$. This study aims to evaluate the mechanical, morphological and thermal behavior of composite thermoplastic polymer matrix of homopolymer polypropylene, reinforced with six different types of natural fibers, with and without the use of polypropylene grafted with maleic an- 
hydride as coupling agent. And, as a reference a glass fiber composite was used.

\section{MATERIALS AND METHODS}

The natural fibers used were: wood flour (Pinus Ellioti), sugarcane (Saccharum spp), bamboo, babassu (Orbignya phalerata), coconut and kenaf, without any prior surface treatment and neither were dried in an oven. The natural fibers used are residues from agroindustrial processes. The homopolymer polypropylene employed in this work was a commercial grade PP. Its melt flow index (MFI) was $3.5 \mathrm{~g} / 10 \mathrm{~min}\left(230^{\circ} \mathrm{C}\right.$, $2.16 \mathrm{~kg}$ ). The coupling agent (CA) used was grafted copolymer of polypropylene with maleic anhydride (PPg-MA), MFI of $200 \mathrm{~g} / 10 \mathrm{~min}\left(190^{\circ} \mathrm{C}, 2.16 \mathrm{~kg}\right)$. The reference composite was glass fiber-reinforced polypropylene $(40 \%$ glass fiber $+60 \%$ PP - w/w - GFPP) produced by Petropol (Petrotene A3 G40 PRTA011 PH366) and MFI of1 $1 \mathrm{~g} / 10 \mathrm{~min}$. The composition for the studied composites are shown in Table 1.

Table 1: Composition of composites (\% - w/w) reinforced with wood flour (WF), sugarcane (SC), bamboo (BB), babassu (BS), coconut (CC) and kenaf (KF) fibers.

\begin{tabular}{lcccc}
\hline \multicolumn{1}{c}{ Sample } & hPP & PP-g-MA & Natural Fiber & Glass Fiber \\
\hline PP + GFPP & 60 & - & - & 40 \\
PP + WF & 60 & - & 40 & - \\
PP + (CA) + WF & 54 & 6 & 40 & - \\
PP + SC & 60 & - & 40 & - \\
PP + BB & 60 & - & 40 & - \\
PP + BS & 60 & - & 40 & - \\
PP + (CA) + BS & 54 & 6 & 40 & - \\
PP + CC & 60 & - & 40 & - \\
PP + KF & 60 & - & 40 & - \\
\hline
\end{tabular}

The particles of wood flour, sugarcane and babassu were separated using an automatic vibratory sieve shaker. The particle size distributions of the fibers were determined with a sieve separation (Bertel). The device was equipped with the following sieves (in order from the largest to the smallest): $35,45,60,80,170$ and 325 mesh, respectively. Natural fiber $(20 \mathrm{~g})$ was placed on top of the 35 mesh sieve and the amount of fiber on each sieve after 20 minutes under vibration was determined gravimetrically. The calculated particle size distributions are listed in Table 2.

Table 2: Particle size distribution (\%) of the natural fibers.

\begin{tabular}{|c|c|c|c|c|c|c|}
\hline Sieve & WF & $\mathrm{SC}$ & $\mathrm{BB}$ & $\mathrm{BS}$ & $\mathrm{CC}$ & KF \\
\hline 35 mesh $(500 \mu \mathrm{m})$ & 2.44 & 12.18 & 27.61 & 27.40 & 39.80 & 51.05 \\
\hline 45 mesh $(354 \mu \mathrm{m})$ & 34.14 & 22.51 & 32.41 & 37.26 & 41.64 & 20.54 \\
\hline 60 mesh $(250 \mu \mathrm{m})$ & 30.25 & 28.05 & 26.24 & 22.57 & 9.39 & 13.11 \\
\hline 80 mesh $(178 \mu \mathrm{m})$ & 25.47 & 17.55 & 9.45 & 7.84 & 3.64 & 7.74 \\
\hline $170 \operatorname{mesh}(89 \mu \mathrm{m})$ & 6.70 & 14.43 & 3.99 & 4.24 & 1.62 & 5.60 \\
\hline $325 \operatorname{mesh}(45 \mu \mathrm{m})$ & 1.00 & 5.16 & 0.15 & 0.69 & 1.35 & 1.96 \\
\hline Background & 0.00 & 1.12 & 0.15 & 0.00 & 2.56 & 0.00 \\
\hline
\end{tabular}

Mixtures were processed on a double screw extruder (25 mm diameter and L/D: 44), with temperature profile of $100^{\circ}$ to $185^{\circ} \mathrm{C}$, screw speed of $290 \mathrm{rpm}$, output of $15 \mathrm{~kg} / \mathrm{h}$, and cut in the "pellets form". The specimens test were prepared by injection molding (CDC 250/50 - Battenfeld) at temperature profile of $180^{\circ}$ to $195^{\circ} \mathrm{C}$ and pressure of 80 bar for mechanical and thermal tests.

Tensile testing was performed in accordance with EN ISO 527 using an Emic machine (Model DL $500 \mathrm{BF}$ ). Test speed was $5 \mathrm{~mm} / \mathrm{min}$ and $5000 \mathrm{~N}$ load cell. Flexural testing was performed in accordance with EN ISO 178, test speed was $10 \mathrm{~mm} / \mathrm{min}$. Charpy impact testing was performed in accordance with EN ISO 179. The heat deflection temperature (HDT) was performed in accordance with EN ISO 75 in Ceast Vicat/HDT Junior (model 6910). The Vicat softening temperature test was made in the same with heat deflection temperature (HDT) equipment with EN ISO 306. Density measurements were performed in accordance with EN ISO 1183-A.

The morphology (Scanning Electron Microscopy - SEM) of the samples was carried out with a Hitachi TM3000 scanning electron microscope operating at $5 \mathrm{kV}$. 
A Perkin Elmer, model Jade, differential scanning calorimeter was used to analyze the specific heat, the crystallization temperature and the crystallinity of the samples. The measurements consist of: heating from $25^{\circ} \mathrm{C}$ up to $200^{\circ} \mathrm{C}$, cooling back to $25^{\circ} \mathrm{C}$ and heating again up to $200^{\circ} \mathrm{C}$, with heating and cooling rate of $10^{\circ} \mathrm{C} / \mathrm{min}$.

The degree of crystallinity $(\mathrm{Xc})$ was determined from the exothermic and the endothermic peaks with Eq. (1), considering melting fusion $\left(\Delta \mathrm{H}_{\mathrm{f}}^{\mathrm{o}}\right)$ with isotatic PP $100 \%$ crystalline of $165 \mathrm{~J} / \mathrm{g}[1]$.

$$
\mathrm{Xc}=\left(\frac{\Delta \mathrm{H}^{\circ} \text { speciment }}{\Delta \mathrm{H}^{\circ} \mathrm{f}}\right) \times 100
$$

The composites were analyzed using a Dynamic Mechanical Analysis (DMA) Q800 TA Instruments. As parameters were utilized $1 \mathrm{~Hz}$ for frequency, with heating rate of $2^{\circ} \mathrm{C} / \mathrm{min}$ and a temperature range of 30 to $150^{\circ} \mathrm{C}$. The mode utilized was three point bending. The dimensions of specimens were: $4 \times 10 \times 64 \mathrm{~mm}$ (thickness $\mathrm{x}$ cross-sections $\mathrm{x}$ length).

\section{RESULTS AND DISCUSSION}

Composites with natural fibers and grafted polypropylene (PP-g-MA) as coupling agent showed the highest results both for tensile strength and flex modulus, $\mathrm{PP}+(\mathrm{CA})+\mathrm{WF}$ and $\mathrm{PP}+(\mathrm{CA})+\mathrm{FBS}$ (Figure 1). The presence of coupling agent in these composites, compared with the same material without $\mathrm{CA}$, confirm the superior interaction between the matrix and the reinforcing fiber at the composite's interface. This treated interface allowed the matrix to transfer the loaded tension to the reinforcing component by chemical interaction or mechanical anchoring [4]. The micrographs show (Figure 3) the absence of empty spaces between the fiber and the matrix, pointed out by the arrows in white, confirming the results evaluation.

The composite PP $+\mathrm{GFPP}$, showed the best results in tensile strength and flexural modulus, Figure 1-a, compared to the polypropylene composites with natural fibers regardless of the presence or not of the coupling agent. SPINACÉ et al. [2] and ETAATI et al. [11] also observed this behavior, once natural fibers are usually less resistant than glass fibers. Although the composites with natural fibers have lower mechanical properties when compared to glass fiber composite, the difference is relatively small, for instance the wood fiber composite with coupling agent $(\mathrm{PP}+(\mathrm{CA})+\mathrm{WF})$ showed Flexural modulus of $69.56 \mathrm{MPa}$ versus 75.78 $\mathrm{MPa}$ for the reference composite ( $\mathrm{PP}+\mathrm{GFPP})$. Coconut fiber had a higher percentage of its fibers with larger particle size, Table 2, this could contributed to the lower results for the $\mathrm{PP}+\mathrm{CC}$ composite, Figure 1-a. There is a lack of adhesion between the coconut fiber and the polypropylene, as can be seen in Figure 3-1d, in addition to that the shape of the fiber being relatively spherical does not help the interaction at the interface, which can also be seen in Figure 3-1d.

The composite reinforced with bamboo fiber showed elastic modulus $14 \%$ higher than $\mathrm{PP}+\mathrm{WF}$, by analyzing the micrograph of the composite $\mathrm{PP}+\mathrm{BB}$, Figure 3-1a, it can be concluded that this result is associated with the interface filler/polymer matrix. It can be seen a great mechanical anchoring between the fiber and the matrix, which is probably related to the high surface roughness of the fiber.
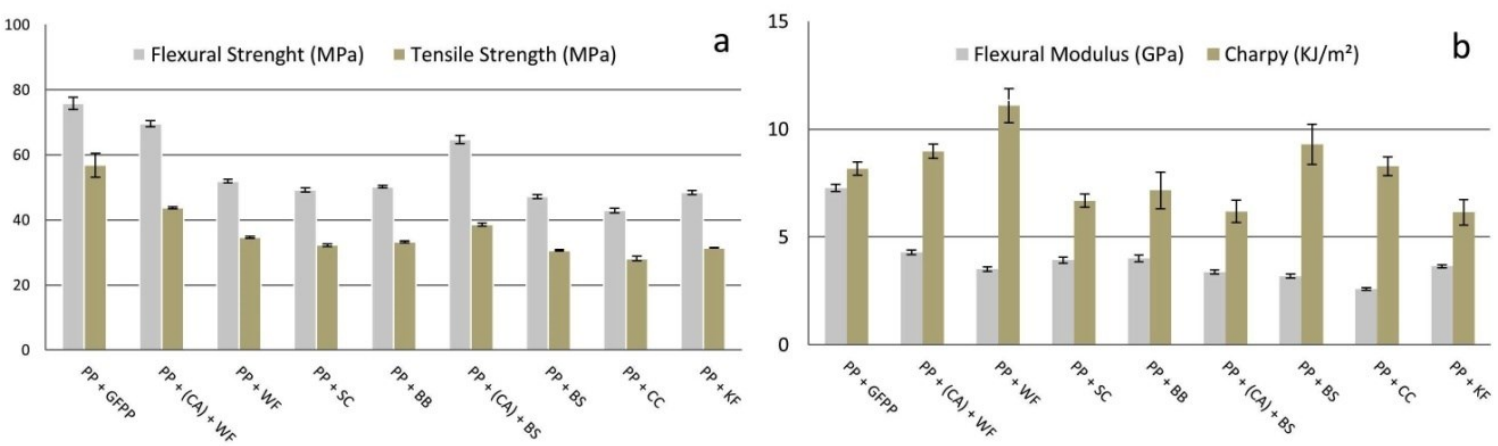

Figure 1: Mechanical results from: a) tensile strength and flexural; and b) Charpy's impact fracture energy and flexural modulus for PP composites reinforced with fibers.

Composites without additive: babassu (PP+BS), coconut $(\mathrm{PP}+\mathrm{CC})$ and wood flour $(\mathrm{PP}+\mathrm{WF})$ fibers showed the best results of Charpy impact (Figure 1-b). In other words, the tenacity thereof in relation to other 
composites, including composite $\mathrm{PP}+\mathrm{GFPP}$ is higher, they are less rigid, as shown by the modulus of elasticity in Figure 1-b, and absorb more impact energy.

Similar behavior was encountered by GOMES et al. [14] comparing banana fiber with glass fiber in high density polyethylene matrix; and, SANTOS et al. [12] compared curauá fiber with glass fiber in Polyamide- 6 matrix. The lower modulus of elasticity was obtained by natural fiber composites without additives $\mathrm{PP}+\mathrm{BS}$ and $\mathrm{PP}+\mathrm{CC}$, being the lowest result obtained by the composite $\mathrm{PP}+\mathrm{BS}$ attributed to poor adhesion of the babassu fibers to the polypropylene matrix, as can be observed in Figure 3-1b, from which the fiber could be easily removed. This poor adhesion was also reported by CARVALHO et al.[17] in a study with polypropylene composites reinforced with babassu fibers. In case of $\mathrm{PP}+\mathrm{CC}$ composite the observed lower module is related to weak interaction at the interface, the shape relatively spherical of the fiber does not contribute for reinforcement. The addition of rigid fillers to the polymer matrix tends to produce more rigid and less resistant materials. In general the elastic modulus of all the composites with natural fibers showed lower mechanical properties when compared to reference material (PP+GFPP), Figure 1-b. The transfer of the applied stress can be hampered by the presence of discontinuous short fibers dispersed in the polymeric matrix, thus reducing tension supported by the composite $[\underline{2}, \underline{12}-\underline{13}]$.

The bamboo fiber composite ( $\mathrm{PP}+\mathrm{BB}$ ) showed interesting results in relation to the modulus of elasticity because, although not contain maleic anhydride in the composition, the modulus of elasticity approached the modulus of elasticity of the wood flour composite with coupling agent $(\mathrm{PP}+(\mathrm{CA})+\mathrm{WF})$. In the Figure 2-a are showed the results obtained for the thermal behavior of composites. The higher Vicat softening point was found to the composite with compatibilized wood fibers $(\mathrm{PP}+(\mathrm{CA})+\mathrm{WF})$ followed by the composite with compatibilized babassu fiber $(\mathrm{PP}+(\mathrm{CA})+\mathrm{BS})$, largely because of the interface treatment, the composite $\mathrm{PP}+\mathrm{GFPP}$ showed similar softening temperature. The highest HDT value was achieved by $\mathrm{PP}+\mathrm{GFPP}$, showing that the natural fibers reduced heat deflection temperature when compared to glass fiber reinforced composite.

Regarding the natural fibers composites, the $\mathrm{PP}+(\mathrm{CA})+\mathrm{WF}$ was second highest to the glass fiber. As can be seen in Figure 2-b, the composite with glass fiber, $\mathrm{PP}+\mathrm{GFPP}$, has higher density than the composites reinforced by natural fibers, that are, on average, $14 \%$ lighter. Among the composites with natural fibers, $\mathrm{PP}+\mathrm{KF}$ composite showed higher density and the composite $\mathrm{PP}+\mathrm{WF}$ and $\mathrm{PP}+\mathrm{BS}$ had the lowest densities. In a study of a composite polyamide- 6 reinforced with curaua fiber relative to a composite with the same matrix reinforced with glass fiber [15] also observed this behavior, which is explained by the higher density glass fiber compared natural fibers [16].
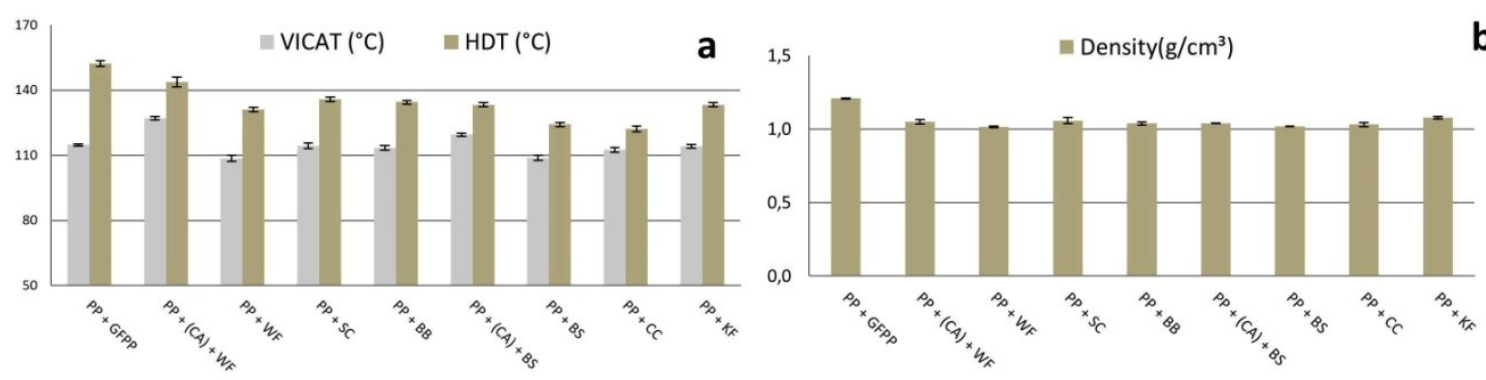

Figure 2: a) Heat deflection temperatures and Vicat softening temperatures; and, b) density for PP composites reinforced with fibers.

Table 3 presents the results for the crystallinity degree with biocomposites reinforced with all types of fibers evaluated. The crystallinity degree of composites, composite $\mathrm{PP}+\mathrm{KF}$ and $\mathrm{PP}+\mathrm{BB}$ were lower than the pure polypropylene, however, in other composites the crystallinity degree compared to pure polypropylene was higher, suggesting that the fibers would act as nucleation agent increasing crystallization of the polypropylene matrix. The increase in the crystallinity degree was also observed by SOCCALINGAME et al [19]. 
Table 3: Crystallinity degree (Xc) for PP composites reinforced with fibers.

\begin{tabular}{lc}
\hline Sample & $\mathrm{Xc}(\%)$ \\
\hline $\mathrm{PP}$ & 59.46 \\
$\mathrm{PP}+\mathrm{GFPP}$ & 69.24 \\
$\mathrm{PP}+\mathrm{WF}$ & 69.22 \\
$\mathrm{PP}+(\mathrm{CA})+\mathrm{WF}$ & 56.95 \\
$\mathrm{PP}+\mathrm{SC}$ & 66.05 \\
$\mathrm{PP}+\mathrm{BB}$ & 51.55 \\
$\mathrm{PP}+\mathrm{BS}$ & 67.94 \\
$\mathrm{PP}+(\mathrm{CA})+\mathrm{BS}$ & 56.59 \\
$\mathrm{PP}+\mathrm{CC}$ & 61.01 \\
$\mathrm{PP}+\mathrm{KF}$ & 44.93 \\
\hline
\end{tabular}

In micrograph of the fractured surface by tensile the composite $\mathrm{PP}+\mathrm{WF}$, Figure 3-1a, it's possible to observe void spaces (indicated by the arrow) between the fiber and the matrix, showing that despite a mechanical anchoring, there is a weak adhesion at the interface between the two phases (matrix and reinforcement) because the polypropylene matrix is non-polar and the fiber is polar. The presence of maleic anhydride coupling agent (CA), caused a chemical interaction between the wood fiber and polypropylene, which gave a good adhesion between the phases. Figure 3-1b, shows the absence no void spaces between the fiber and the matrix, indicating good adhesion at $\mathrm{PP}+(\mathrm{CA})+\mathrm{WF}$ composite's interface. The voids spaces between the fiber and the matrix, indicated by the arrows in Figure 3-1c, show that there is a weak interaction at the interface only due to mechanical anchoring among the sugarcane fiber and the matrix. Coconut fiber has a different format from the other fibers studied, as can be seen in the photomicrograph of Figure 3-1d, the coconut fiber is relatively spherical, which explains the thermal and mechanical strength results for the $\mathrm{PP}+\mathrm{CC}$ composite; also voids between the coconut fiber and the polypropylene matrix are observed.

The composite $\mathrm{PP}+40 \%$ bamboo fiber although not contain a coupling agent in its formulation, showed almost no voids between fiber and matrix, Figure 3-2a (white arrow). This is probably related to the high surface roughness of bamboo fiber that allows the mechanic interlocking with the matrix. The cavity shown by the yellow arrow in Figure 3-2a is derived from the pull out of fibers during the tensile test. The composite interface explains the good results obtained by the composite $\mathrm{PP}+\mathrm{BB}$ in thermal resistance and mechanical tests.

The babassu fiber, different from all other fibers studied, does not have a surface with high roughness, resulting in a weak contact surface between the fiber and the matrix, in addition to not having chemical interactions between the phases due to different nature of the fiber and the polymer matrix. The cavity indicated by the yellow arrow in Figure 3-2b is also originated of the pull out of the fibers during the tensile test. The lack of interaction fiber / matrix explains the results of the composite $\mathrm{PP}+\mathrm{BS}$ in thermal resistance and mechanical tests and how easy is manually removing the fiber of the matrix.

As observed in the composite $\mathrm{PP}+40 \%$ wood fiber $+\mathrm{CA}$, the coupling agent maleic anhydride (CA) caused a chemical interaction between the babassu fiber and polypropylene, which gave an improvement in adhesion between the phases, but not sufficient to prevent pull out of fibers at some points of the polymer matrix, as can be observed in the composite photomicrograph PP+BS (Figure 3-2c, yellow arrow). The behavior occurred in other composites without maleic anhydride, was again observed in the composite $\mathrm{PP}+40 \%$ kenaf, Figure 3-2d, where there is no chemical interaction between the fiber and the matrix, however, there is only contact through mechanical anchoring of the fiber in the matrix polymer due to the roughness of the fiber surface. 

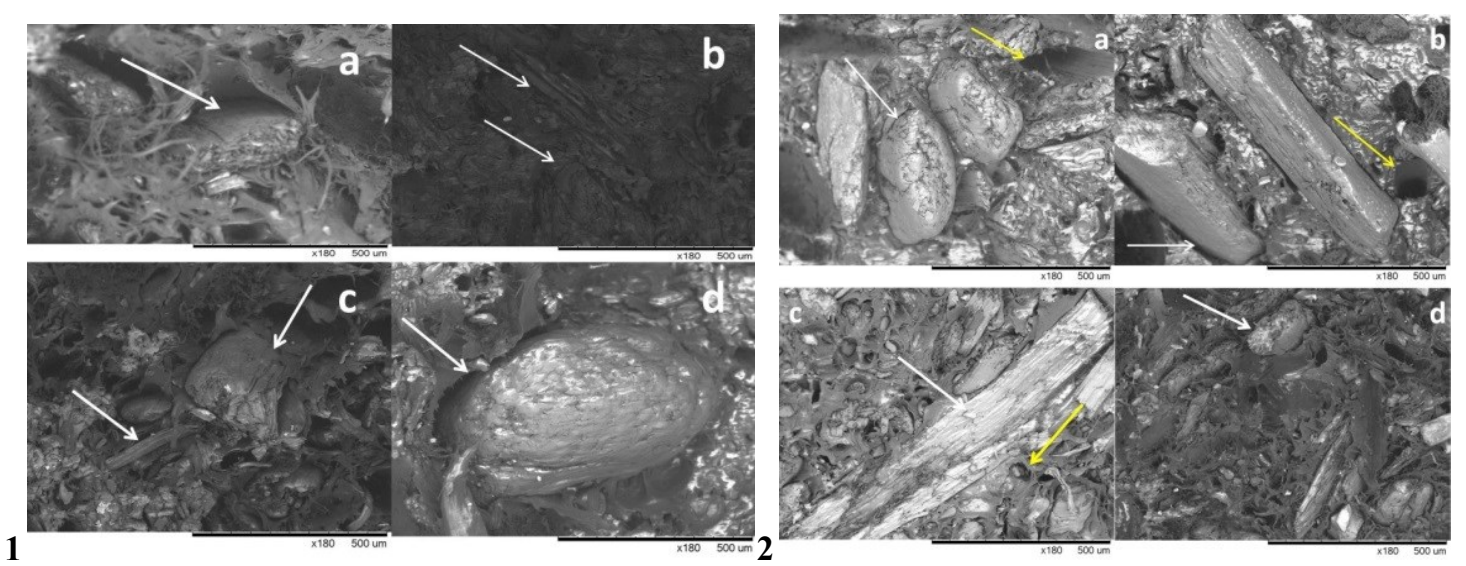

Figure 3: SEM surface composites with fibers at 180x magnification rates: 1 - (a) PP + WF, (b) PP + (CA) + WF, (c) PP $+\mathrm{SC}$ and (d) PP + CC; and, 2 - (a) PP + BB, (b) PP + BS, (c) PP + (CA) + BS and (d) PP + KF.

The composite $\mathrm{PP}+40 \%$ glass fiber, as well as composites with vegetable fibers without additives with maleic anhydride, had voids between the glass fiber and the polypropylene matrix, Figure 4 (yellow arrow), indicating the lack of chemical interaction between fiber and matrix, i.e., the only interaction is due to mechanical anchoring. Thermal resistance and mechanical tests for this composite showed the best results, with the exception of Charpy impact and density because, although there is a poor fiber/matrix interface, the fiber glass supports larger loads when compared to the natural fiber.

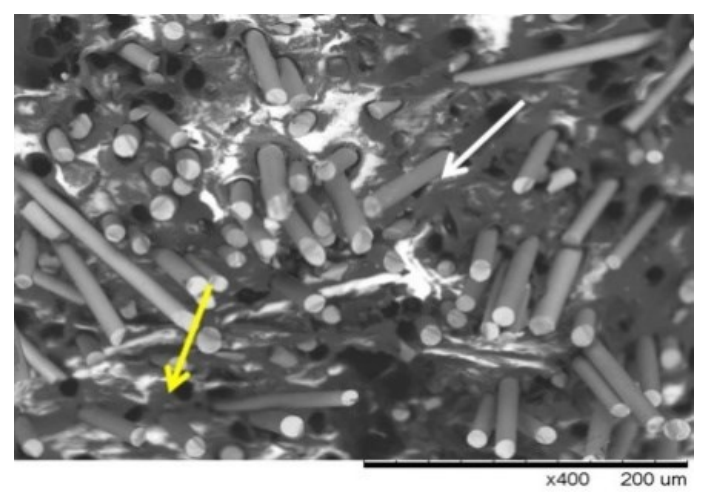

Figure 4: SEM PP + GFPP at 400x magnification.

Figure 5 shows the results of dynamic mechanical thermal analysis (DMTA). With increasing temperature there is a decrease in storage modulus for all the composites as expected and also observed by ETAATI et al [11], PANAITESCU et al [20] and ROSARIO et al [21]. Independent of the temperature, composite PP + GFPP showed higher storage modulus than all other composites including the ones with coupling agent, Figure 5-a and Figure 5-b, such result was expected due to the reinforcing fiber. Considering the composites without additives, material with sugarcane fiber showed the best results for three $\left(30^{\circ} \mathrm{C}, 80^{\circ} \mathrm{C}\right.$ and $\left.120^{\circ} \mathrm{C}\right)$ of four temperatures selected for this analysis $\left(30^{\circ} \mathrm{C}, 80^{\circ} \mathrm{C}, 120^{\circ} \mathrm{C}\right.$ and $\left.150^{\circ} \mathrm{C}\right)$.

The bamboo fiber reinforced composite had the best result at $150^{\circ} \mathrm{C}$, Figure 5-b. Figure 5-c showed the behavior of all the composites considering the type of analysis, static (flexural modulus) or dynamic (storage modulus), and their behavior is similar, although the values for the static test are higher. During the DMA test occurs storage and dissipation of energy, this loss of energy is associated with several factors including imperfections that the composite could contain, and the friction between matrix and the fiber, the weaker the interface fiber / matrix the higher will be the energy dissipation and lower will be the storage modulus [11]. This effect can be seen in the comparison between composites reinforced with the same fiber but with and without coupling agent. Figure 5-d presents the results of composites $\mathrm{PP}+\mathrm{WF}, \mathrm{PP}+(\mathrm{CA})+\mathrm{WF}$, $\mathrm{PP}+\mathrm{BS}$ and $\mathrm{PP}+(\mathrm{CA})+\mathrm{BS}$, it was observed that the presence of coupling agent increased the storage modulus. 

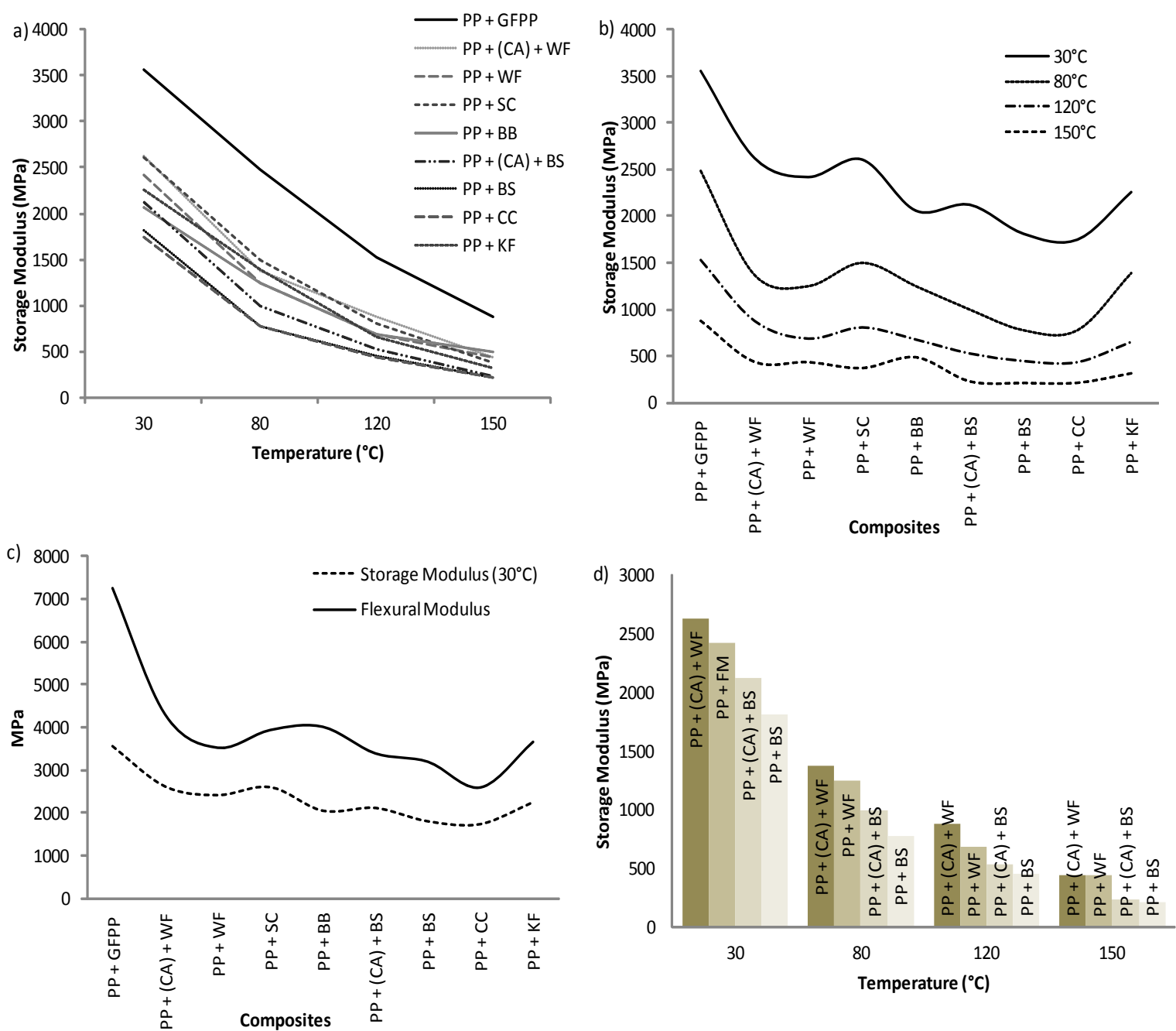

Figure 5: a) and b) Storage Modulus x temperature: All composites; c) Comparison: Flexural Modulus x Storage Modulus; d) Comparison Storage Modulus: Composites with and without coupling agent.

\section{CONCLUSIONS}

The thermal, mechanical and morphological performances of the composites reinforced with natural fibers are lower than the glass fiber reinforced composite, but in some cases the difference is not significant. The use of coupling agent in composites with natural fibers brought gains in both thermal properties as in mechanical property and can expand the applications of these composites in the automotive industry. Each studied fiber type provides different properties to their respective composite that can guide their selection and usage. The composites with coconut fiber, babassu fiber and wood fiber can be used in applications where impact resistance is an important item because, showed the best performance. In applications where thermal resistance is critical, the composite with polypropylene, coupling agent and wood flour may be an alternative, because results are similar to the glass fiber composite. The density is still an advantage of using natural fibers as reinforcing agents in composites, meaning weight reduction for the parts, and less fuel consumption for vehicles. The results opened a great number of possibilities for using these materials in various applications depending on the required properties.

\section{ACKNOWLEDGEMENTS}

The authors are grateful to FINEP, Kraton Polymers LLC, Federal Universityof São Carlos (UFSCar/Campus Sorocaba)and Artecola Quimica S.A. by providing raw-materials and analysis.

\section{BIBLIOGRAPHY}

[1] BECKER, D., KLEINSCHMIDT, A. C., BALZER, P. S., et al., "Influência da Sequência de Mistura do PP-MA nas Propriedades dos Compósitos de PP e Fibra de Bananeira”, Polímeros, v. 21, n. 1, pp. 7 - 12 , 
Fev.2011

[2] SPINACÉ, M. A. S., JANEIRO, L. G., BERNARDINO, F. C., et al.,"Poliolefinas reforçadas com fibras vegetais curtas: sisal $\times$ curauá", Polímeros, v. 21,n. 3, pp. 168 - 174, Jun. 2011

[3] SILVA, R., HARAGUCHI, S. K., MUNIZ, E.C., et al., "Aplicações de fibras lignocelulósicas na química de polímeros e em compósitos", Química Nova, v. 32, n. 3, pp. 661 - 671, Abr. 2009

[4] CORREA, C.A., FONSECA, C.N.P., NEVES, S., et al.,“Compósitos Termoplásticos com Madeira”, Polimeros, v.13, n.3, pp. $154-165$, Set. 2003

[5] JOHN, M. J., BELLMANN, C., ANANDJIWALAA, R. D., "Kenaf-polypropylene composites: Effect of amphiphilic coupling agent on surface properties of fibres and composites", Carbohydrate Polymers, v. 82, n.3, pp. $549-554$, Oct. 2010

[6] FIDELIS, M. E. A., PEREIRA, T. V. C., GOMES, O. F. M., et al.,"The effect of fiber morphology on the tensile strength of natural fibers", J Mater Res Technol.,v. 2, n. 2, pp. 149-157, Jun. 2013

[7] LEMOS, A. L., MARTINS, R. M., "Desenvolvimento e caracterização de compósitos poliméricos à base de poli (ácido lático) e fibras naturais”, Polímeros, v. 24, n. 2, pp. 190 - 197, Abr. 2014

[8] FARUK, O., BLEDZKI, A. K., FINK, H.-P., et al., "Progress report on natural fiber reinforced composites", Macromolecular Materials and Engeneering, v. 299, n. 1, pp. 9-26, Jan. 2014

[9] SOBCZAK, L., LANG, R. W., HAIDER, A., "Polypropylene composites with natural fibers and wood General mechanical property profiles", Composites Science and Technology, v.72, n. 5, pp. 550 - 557, Mar. 2012

[10] DICKSON, A. R., EVEN, D., WAMES, J. M., et al., "The effect of reprocessing on the mechanical properties of polypropylene reinforced with wood pulp, flax or glass fibre", Composites: Part A, v. 61, pp. $258-267$, Jun. 2014

[11] ETAANI, A., PATHER, S., FENG, Z., et al.,"The study of fibre/matrix bond strength in short hemp polypropylene composites from dynamic mechanical analysis", Composites: Part B, v. 62, 19 - 28, Jun. 2014

[12] SANTOS, E. F., MORESCO, M., ROSA, S. M. L., et al.,"Extrusão de Compósito de PP com Fibras Curtas de Coco: feito da Temperatura e Agentes de Acoplamento", Polímeros, v. 20, n. 3, pp. 215 - 220, Out. 2010

[13] HUDA, S., REDDY, N., YANG, Y.,"Ultra-light-weight composites from bamboo strips and polypropylene web with exceptional flexural properties", Composites: Part B, v. 43, N. 3, pp. 1658 - 1664, Apr. 2012

[14] GOMES, T. S., VISCONTE, L. L. Y.,PACHECO, E. B. A. V.,"Substituição de fibra de vidro por fibra de bananeira em compósitos de polietileno de alta densidade. Parte 1. Avaliação mecânica e térmica", Polímeros, v. 23, n. 2, pp. $206-211$, Fev. 2013

[15] SANTOS, P. A., SPINACÉ, M. A. S., FERMOSELLI, K. K. G., et al.,"Efeito da forma de processamento e do tratamento da fibra de curauá nas propriedades de compósitos com poliamida-6", Polímeros: Ciência e Tecnologia, v. 19, n. 1, pp. $31-39,2009$

[16] KHALIL, H.P.S.A., BHAT, I.U.H., JAWAID, M., et al.,"Bamboo fibre reinforced biocomposites: A review", Materials and Design, v. 42, pp. 353-368, Dec. 2012

[17] CARVALHO, L. H., ALVES, T. S., PORTO, L. S., et al, "Desempenho e Caracterização de Compósitos Polímero/Fibra de Babaçu”, Congresso Plastshow, São Paulo, Brasil, 06-09 Abril 2010

[18] LUZ, S.M., DEL TIO, J., ROCHA, G. J. M., et al., "Cellulose and cellulignin from sugarcane bagasse reinforced polypropylene composites: Effect of acetylation on mechanical and thermal properties", Composites: Part A, v. 39, n. 9, pp. 1362 - 1369, Sep. 2008

[19] SOCCALINGAME, L., BOURMAUD, A., PERRIN, D., et al., "Reprocessing of wood flour reinforced polypropylene composites: Impact of particle size and coupling agent on composite and particle properties", Polymer Degradation and Stability, v. 113, pp. 72 - 85, Mar. 2015

[20] PANAITESCU, D.M., VULUGA, Z., GHIUREA, M., et al.,"Influence of compatibilizing system on morphology, thermal and mechanical properties of high flow polypropylene reinforced with short hemp fibres", Composites: Part B, v. 69, pp. 286 - 295, Feb. 2015

[21] ROSÁRIO, F., PACHEKOSKI, W.M., SILVEIRA, A. P.J, et al.,"Resíduo de Sisal como reforço em compósitos de polipropileno virgem e reciclado", Polímeros, v. 21, n. 2, pp. 90 - 97, Abr. 2011. 